\title{
Perancangan Prototype Mesin Pengayak Pasir Semi Otomatis Menggunakan Photovoltaic \\ ${ }^{1}$ Dionisia Rue, ${ }^{2}$ Irrine Budi Sulistiawati, ${ }^{3}$ Ni Putu Agustini \\ ${ }^{1,2,3}$ Program Studi Teknik Elektro, Fakultas Teknik Industri, Institut Teknologi Nasional, Malang \\ ${ }^{1}$ druee12@gmail.com, ${ }^{2}$ irrine@ @lecturer.itn.ac.id, ${ }^{3}$ ni_putu_agustini@ @ecturer.itn.ac.id
}

\begin{abstract}
Article Info
Article history:

Received February $11^{\text {th }}, 2021$

Revised February $20^{\text {th }}, 2021$

Accepted March $21^{\text {th }}, 2021$

\section{Keyword:}

Brushless Direct Current Motor

Solar Panel

Accumulator
\end{abstract}

Sand Sift

\section{Corresponding Author:}

Dionisia Rue,

Department of Electrical Engineering, National Institute of Technology,

Malang.

Email: druee12@gmail.com

Abstrak - Sistem pengayakan pasir umumya masih dilakukan secara manual yang memerlukan tenaga manusia secara penuh untuk proses pengayakan. Hal ini cukup memakan waktu lama serta massa pasir halus yang dihasilkan masih jauh dari yang diperlukan untuk proyek pembangunan. Maka dari itu penulis membuat ide rancang bangun mesin pengayak pasir yang dapat diterapkan dimana saja. Mesin ini menggunakan sistem penggerak dari motor listrik Brushlesss Direct Current berkapasitas 350W sebagai motor penggerak. Motor Brushless Direct Current Motor digunakan karena memiliki keunggulan torsi awal yang besar, kecepatan yang lebih tinggi karena tidak menggunakan brush. Sebagai sumber tenaga listrik digunakan energy baru terbarukan Panel Surya berkapasitas 400Wp yang lebih ramah lingkungan dan efisien. Mesin ini bekerja ketika panel surya menyuplai sumber listrik ke motor penggerak dan kemudian ditransmisikan oleh rantai dan gear ke tabung ayakan untuk proses pengayakan. Mesin ini lebih lebih cepat proses pengayakan pasirnya dibandingkan mengayak secara manual serta jenis motor yang digunakan lebih efisien.

\section{Pendahuluan}

\section{A. Latar belakang}

Seiring perkembangan zaman kemajuan teknologi semakin cepat berkembang. Majunya teknologi terasa diberbagai sektor kehidupan salah satunya sektor pembangunan infrastruktur. Pembangunan infrastruktur yang sederhana misalnya rumah tinggal juga tak lepas dari teknologi. Salah satu bahan utama yang diperlukan dalam pembangunan adalah pasir. Proses pengolahan pasir pun kini dimudahkan dengan adanya teknologi.

Persediaan pasir daerah Timur Indonesia sangat melimpah. Namun, masih kendala dalam teknologi pengolahan pasir 
khususnya dalam proses pengayakan pasir. Di daerah Timur Indonesia, pengayakan pasir umumnya masih dilakukan secara manual dengan alat pengayak sederhana. Proses pengayakan memerlukan tenaga manusia dua atau lebih untuk mengayak pasir guna memperoleh pasir halus yang diperlukan untuk proses pembangunan. Hal ini cukup memakan waktu serta massa pasir yang dihasilkan pun masih kurang dari yang dibutuhkan.

Beberapa waktu belakangan, kini telah dikembangkan mesin-mesin pengayakan pasir untuk memudahkan proses pembangunan dengan memanfaatkan motor listrik sebagai penggerak mesin. Supply listrik untuk penggerak motor diperoleh dari PLN. Nam|un, hal ini sulit bila diterapkan di Indonesia Timur karena pemerataan listrik di daerah Timur sendiri masih belum merata terlebih di daerah-daerah terpencil.

Berawal dari permasalahan ini penulis terinovasi untuk merancang mesin pengayak pasir secara semi-otomatis untuk memudahkan proses pembangunan didaerah Timur Indonesia. Mesin ini direncanakan akan menggunakan motor listrik BLDC karena motor listrik jenis ini memerlukan daya yang lebih kecil. Untuk supply motor listrik akan memanfaatkan energi terbarukan yakni panel surya yang lebih ramah lingkungan. Karena energi yang mudah diperoleh ini maka, dengan demikian mesin pengayak pasir ini dapat diterapkan dimana saja termasuk daerah Timur Indonesia.

\section{B. Tinjauan Pustaka}

\section{a) Panel Surya}

Panel surya / solar cell merupakan komponen listrik yang dapat mengubah energi cahaya matahari menjadi energi listrik dengan menggunakan prinsip photovoltaic. Solar cell tersusun dari dua lapisan semikonduktor yang berbeda muatan [1]. Lapisan atas bermuatan negatif sedangkan lapisan bawahnya bermuatan positif.
Bahan semikonduktor yang paling umum digunakan untuk solar cell adalah silikon. Silikon menjadi bahan yang kerap digunakan untuk solar cell karena:

1. Merupakan bahan semikonduktor.

2. Teknologi dikembangkan dengan baik untuk membuat silikon menjadi positif atau pembawa muatan negatif elemen penting untuk sebuah sel listrik atau baterai

3. Silikon berlimpah pasokan dan relatif murah dalam produksi

4. Mikro dan Nano-Teknologi telah meningkatkan Opto-Listrik efisiensi konversi solar cell silicon.

\section{b) Motor Listrik BLDC}

Motor Listrik BLDC atau yang disebut juga PMSM Motor (Permanent Motor Synchronous Motor) merupakan motor listrik synchronous AC 3 fasa yang memakai sumber arus listrik searah sebagai sumber tenaga. Motor BLDC ini bekerja ketika magnet yang berada pada rotor motor ditarik dan didorong oleh gaya elektromagnetik yang diatur pada controller motor dengan bantuan driver motor. Gaya elektromagnetik ini akan mendorong silinder berlubang dan mengakibatkan timbulnya torsi yang menggerakkan motor dengan kecepatan $\omega[2]$. Dibandingkan dengan motor DC jenis lainnya, BLDC memiliki biaya perawatan yang lebih rendah dan kecepatan yang lebih tinggi akibat tidak digunakannya brush. Dibandingkan dengan motor induksi, BLDC memiliki efisiensi yang lebih tinggi dan torsi awal yang tinggi, karena rotor terbuat dari magnet permanen. Motor BLDC memiliki kelebihan dibandingkan dengan motor jenis lain, metode pengendalian motor BLDC jauh lebih rumit untuk kecepatan dan torsi yang konstan, karena tidak adanya brush yang menunjang proses komutasi dan harga untuk motor BLDC jauh lebih mahal.

\section{c) Solar Charger Controller (SCC)}

Solar Charge Controller (SCC) adalah salah satu komponen di dalam sistem pembangkit listrik tenaga surya, 
berfungsi sebagai pengatur arus listrik baik terhadap arus yang masuk dari Panel Surya maupun arus beban keluar/digunakan. Bekerja untuk menjaga baterai dari pengisian yang berlebihan. Solar Charge Controller mengatur tegangan dan arus dari Panel Surya ke baterai. Sebagian besar Panel Surya 12 Volt menghasilkan tegangan keluaran sekitar 16 sampai 20 volt DC, jadi jika tidak ada pengaturan, baterai akan rusak dari pengisian tegangan yang berlebihan. Pada umumnya baterai 12 Volt membutuhkan tegangan pengisian sekitar 13-14 volt (tergantung tipe baterai) untuk dapat terisi penuh[1]

\section{d) Controller Motor BLDC}

Controller motor listrik BLDC merupakan control motor khusus motor listrik BLDC yang mengatur dan mengontrol kecepatan putar motor listrik BLDC. Control motor ini menggunakan PWM (Pulse Width Modulation) PWM merupakan suatu proses perbandingan antara sinyal carrier dengan sinyal modulasi sehingga menghasilkan sinyal kotak dengan lebar pulsa yang berbeda. Lebar pulsa tersebut dapat diatur dengan duty cycle. Duty cycle merupakan prosentase periode sinyal high dan periode sinyal low, presentase duty cycle akan berbanding lurus dengan tegangan rata rata yang dihasilkan. Sinyal PWM memiliki lebar pulsa yang bervariasi sesuai duty cycle

\section{e) Accumulator / Accu}

Accumulator / aki / baterai merupakan sebuah alat yang digunakan untuk menyimpan energi umumnya menyimpan energi listrik dalam bentuk energi kimia. Akumulator jenis timbal setiap satu sel memiliki tegangan sebesar 2 volt, sehingga aki 12 volt memiliki 6 sel, sedangkan aki 24 volt memiliki 12 sel. Accumulator jenis NiCd setiap satu sel memiliki tegangan sebesar 1.2 volt.

\section{f) Prinsip Kerja Dalam Pengisian Accu}

Ketika kondisi tegangan pengisian di baterai telah mencapai keadaan penuh, maka controller akan menghentikan arus listrik yang masuk kedalam baterai untuk mencegah pengisian yang berlebihan. Dengan demikian ketahanan baterai akan jauh lebih tahan lama. Dalam kondisi ini, listrik yang tersuplai dari panel surya akan langsung terdistribusi ke beban / peralatan listrik dalam jumlah tertentu sesuai dengan konsumsi daya peralatan listrik.

Ketika tegangan di baterai dalam keadaan hampir kosong, maka controller berfungsi menghentikan pengambilan arus listrik dari baterai oleh beban / peralatan listrik. Dalam kondisi tegangan tertentu (umumnya sekitar 10\% sisa tegangan di baterai), maka pemutusan arus beban dilakukan oleh controller. Hal ini menjaga baterai dan mencegah kerusakan pada sel - sel baterai.Pada kebanyakan model controller, indicator lampu akan menyala dengan warna tertentu (umumnya berwarna merah atau kuning) yang menunjukkan bahwa baterai dalam proses pengisian. Dalam kondisi ini, bila sisa arus dibaterai kosong (dibawah 10\%), maka pengambilan arus listrik dari baterai akan diputus oleh controller, maka peralatan listrik /beban tidak dapat beroperasi. Pada controller tipe-tipe tertentu dilengkapi dengan digital meter dengan indikator yang lebih lengkap, untuk memonitor berbagai macam kondisi yang terjadi pada sistem pembangkit listrik tenaga surya [1].

\section{g) Pasir}

Pasir adalah merupakan bahan dasarnya diperoleh dari alam yang berupa bahan material butiran. Bedasarkan ukuran butiran pasir umumnya berukuran antara 0,0625 sampai dengan 2 milimeter. Materi pembentukan pasir adalah silikon dioksida, tetapi dibeberapa pantai tropis dan subtropis umumnya dibentuk dari batu kapur. Pasir memiliki warna sesuai dengan asal pembentukannya. Segumpal pasir terdiri dari dua atau tiga bagian. Dalam pasir yang kering hanya akan terdari dua bagian yaitu butir-butir tanah dan pori-pori udara. Dalam pasir yang jenuh juga terdapat dua bagian, yaitu bagian padat atau butiran dan air pori. Dalam keadaan tidak jenuh, pasir terdiri dari tiga bagian, yaitu bagian padat atau butiran, 
pori-pori udara, dan air pori. Ukuran butiran pasir tergantung pada diameter partikel pasir yang membentuk massa tanah.

\section{h) Pengayakan}

Pengayakan adalah suatu unit operasi dimana suatu campuran dari berbagai jenis partikel padat dipisahkan kedalam dua atau lebih bagian-bagian kecil dengan cara melewatkannya diatas ayakan. Atau dengan kata lain pengayakan adalah suatu proses pemisahan bahan berdasarkan ukuran lubang kawat yang terdapat pada ayakan, bahan yang lebih kecil dari ukuran lubang akan masuk, sedangkan yang berukuran besar akan tertahan pada permukaan kawat ayakan.

Pengayakan dengan berbagai rancangan telah banyak digunakan dan dikembangkan secara luas pada proses pemisahan bahan-bahan material berdasarkan ukuran, tetapi pengayak juga digunakan sebagai alat pembersih, dan pemisah yang berbeda ukurannya dari bahan baku. Adapun factorfaktor yang mempengaruhi efisiensi dalam proses pengayakan

i. Bentuk butir, padatan yang berupa butir tidak beraturan lebih mudah lolos dibandingkan dengan bahan-bahan yang berbentuk pola

ii. Gerakan atau waktu tinggal, gerakan atau waktu tinggal bahan diatas ayakan harus dipilih agar setiap butiran paling sedikit satu kali berada pada sebuah lubang ayakan. Efisiensi pengayakan akan turun jika bahan yang di ayak membentuk lapisan yang terlalu tebal atau bergerak terlalu cepat, di samping itu gerakan yang terlalu kuat dapat menyebabkan pengecilan ukuran akibat pengikisan, terutama pada bahan yang lunak.

iii. Kelembaban, bahan yang lembab atau lekat ikut menyebabkan pengumpalan bahan dan menutupi lubang ayakan.

iv. Muatan listrik statis, bahan-bahan organik khusus yang halus mempunyai kecenderungan untuk membentuk gumpalan karena adanya muatan listrik statis, karena itu alat-alat yang digunakan untuk mengayak bahan-bahan organik harus dibersihkan terlebih dahulu.

v. Lubang ayakan.

\section{Metode Penelitian}

\section{A. Metode}

Metode studi literature digunakan dalam penelitian ini untuk mengetahui teori-teori yang berhubungan dengan alat yang akan dirancang. Penelitian ini dilakukan di daerah Flores, Provinsi Nusa Tenggara Timur selama kurun waktu 6 bulan perancangan dan penelitian. Dalam perancangan alat ini ada beberapa tahapan yang digunakan dan dibuat dalam flowchart untuk mempermudah proses perancangan. Tahapan dapat dilihat dalam gambar berikut :
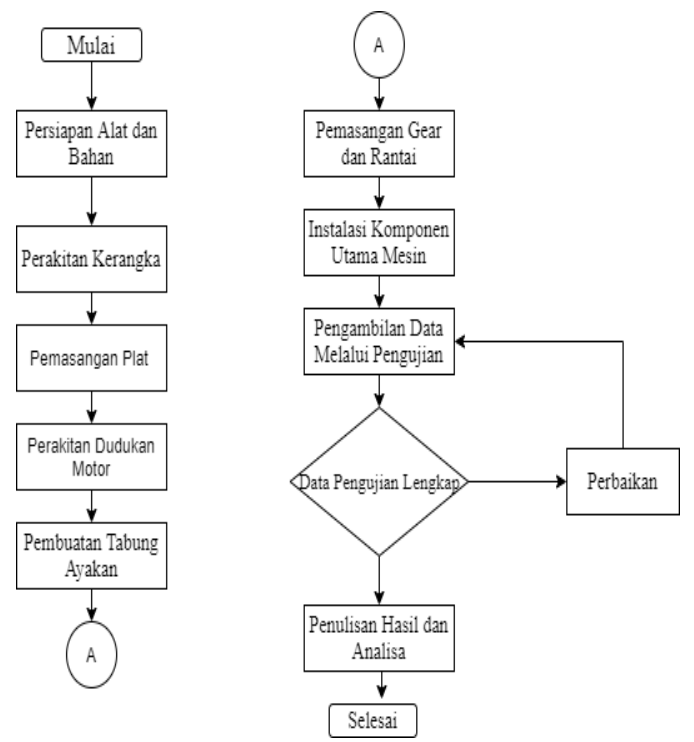

Gambar 1. Flowchart Perancangan Alat 


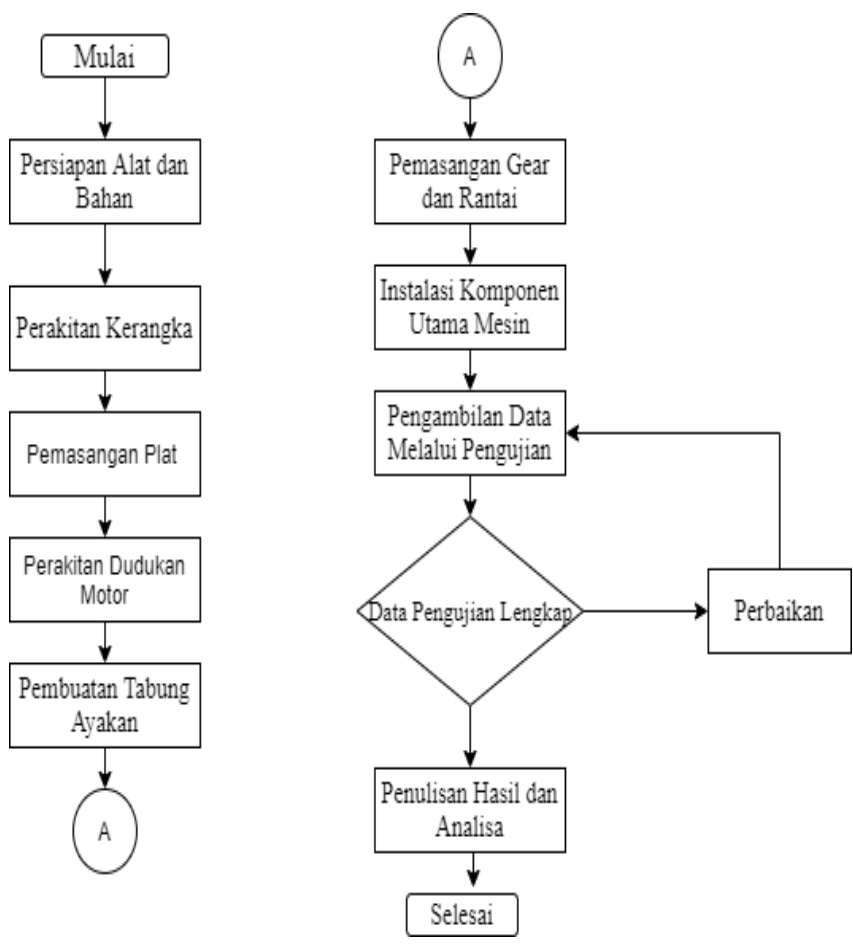

Gambar 2. Flowchart Kerja Sistem

\section{B. Alat dan Bahan}

Pada tahap ini sebelum membuat rancangan mesin pengayak pasir, hal pertama yang harus dilakukan adalah penentuan peralatan dan bahan yang akan digunakan dalam pembuatan mesin pengayak pasir. Peralatan dan bahan yang akan digunakan, yakni sebagai berikut :

\section{Panel Surya / Solar Cell}

Solar cell akan dimanfaatkan sebagai supply DC utama untuk motor penggerak agar motor dapat menggerakan mesin.

2. Motor Listrik BLDC

Motor listrik BLDC akan dimanfaatkan sebagai motor penggerak mesin pengayak.

3. Accumulator / Aki

Accu / aki akan dimanfaatkan sebagai penyimpan daya yang dihasilkan oleh solar cell. Penggunaan aki ini agar daya yang dibutuhkan mesin tetap stabil meskipun kondisi matahari teduh / berawan.

4. Solar Charger Controller
Solar charger controller dimanfaatkan sebagai pengontrol arus yang masuk dari panel surya maupun arus keluar ke beban dan juga sebagai pengisi accu / aki dari panel surya.

5. Control Motor BLDC dan Handle Gas

Control motor dan handle gas akan dimanfaatkan sebagai pengontrol dan pengatur kecepatan putaran motor.

\section{Prinsip Kerja Mesin}

Sistem kerja mesin pengayak pasir ini akan bekerja secara semi otomatis. Prinsip kerja mesin pengayak pasir ialah panel surya akan mengubah energi listrik yang diperoleh dari matahari, energi listrik yang dihasilkan akan disimpan pada accumulator. Energi listrik dari panel surya sebelum masuk ke accumulator akan diterima oleh solar charger controller. Solar charger controller akan mengatur arus yang masuk melalui panel surya agar tetap stabil dan mengontrol pengisian accumulator. Energi listrik yang tersimpan pada accumulator digunakan untuk menggerakan motor listrik BLDC. Accumulator akan dihubungkan dengan control motor BLDC yang telah terhubung dengan motor listrik BLDC. Control motor akan mengatur putaran motor secara akurat dengan mengontrol putaran motor dari putaran minimal ke putaran maksimal menggunakan handle gas sebagai control putarannya. Pada control motor dan accumulator ini akan dipasang MCB sebagai proteksi bila terjadi hubung singkat. Putaran motor BLDC akan menggerakan tabung ayak lewat transmisi gear dan rantai yang terpasang pada motor BLDC dan pada poros tabung ayak. Ketika mesin berhasil bekerja maka pasir kasar akan dimasukkan secara bertahap kedalam tabung ayakan. Tabung ayakan yang berputar akan memisahkan pasir kasar menjadi pasir halus sesuai dengan yang diinginkan untuk keperluan pembangunan. 
D. Spesifikasi Mesin Pengayak

Tabel 1. Data Parameter

\begin{tabular}{|c|c|c|}
\hline No. & Parameter & Ukuran \\
\hline 1. & Lebar Mesin & $80 \mathrm{~cm}$ \\
\hline 2. & Tinggi Mesin & $200 \mathrm{~cm}$ \\
\hline 3. & Panjang Tabung Ayak & $100 \mathrm{~cm}$ \\
\hline 4. & Diameter Tabung Ayak & $54 \mathrm{~cm}$ \\
\hline 5. & Lebar Wadah Pasir Halus & $100 \mathrm{~cm}$ \\
\hline 6. & Lebar Wadah Kerikil & $60 \mathrm{~cm}$ \\
\hline
\end{tabular}

\section{E. Analisa Penentuan Kapasitas Mesin}

1. Menghitung Daya Motor dan Kebutuhan Motor

Motor listrik yang akan digunakan sebagai penggerak mesin perlu ditentukan kapasitasnya agar dapat mengimbangi kerja mesin. Maka dari itu terlebih dahulu menghitung analisa daya motor yang akan digunakan dengan sistematika perhitungan sebagai berikut :

$$
\mathrm{P}=\frac{\mathrm{N} \times \mathrm{T}}{5252}
$$

Ket : $\mathrm{P}=$ Daya Motor $(\mathrm{kW})$

$$
\begin{aligned}
& \mathrm{N}=\text { Kecepatan Putar Motor (rpm) } \\
& \mathrm{T}=\text { Torsi Motor }(\mathrm{Nm})
\end{aligned}
$$

Kecepatan Putar Motor yang direncanakan : $1800 \mathrm{rpm}$

Torsi motor yang direncanakan : 1,12Nm Maka ,

$$
\begin{aligned}
& \mathrm{P} \text { motor }=\frac{1800 \times 1,12}{5252}=0,28311 \mathrm{HP} \\
& 0,28311 \mathrm{HP} \times 745,7 \mathrm{watt}=211,115 \mathrm{watt}
\end{aligned}
$$

Agar dapat mengimbangi kerja mesin maka diperlukan daya motor yang lebih besar yakni 350 watt. Motor listrik BLDC $350 \mathrm{w}$ yang digunakan memiliki spesifikasi bawaan sebagai beikut :
Tabel 2. Kapasitas Motor

\begin{tabular}{|c|c|}
\hline Daya Motor & $350 \mathrm{~W}$ \\
\hline $\mathrm{V}$ & $48 \mathrm{~V}$ \\
\hline Torsi & $1,19 \mathrm{Nm}$ \\
\hline Bongkar Kecepatan & $3100 \mathrm{Rpm}$ \\
\hline Nilai Kecepatan & $2800 \mathrm{Rpm}$ \\
\hline $\mathrm{I}_{\text {tanpa beban }}$ & $9,4 \mathrm{~A}$ \\
\hline $\mathrm{I}_{\text {dengan beban }}$ & $2,8 \mathrm{~A}$ \\
\hline
\end{tabular}

2. Menghitung Kebutuhan Accu

Daya pada accu bergantung pada banyaknya energi yang dapat disimpan, energi yang tersimpan dalam sebuah baterai dalam satuan Ah (Ampere hour), sehingga dapat mengetahui total kapasitas arus dengan tegangan kerja baterai. Jika menggunakan accu dengan kapasitas 50Ah $12 \mathrm{~V}$ maka :

Tabel 3. Kapasitas Accu

\begin{tabular}{|c|c|c|}
\hline Parameter & $\begin{array}{c}1 \text { buah } \\
\text { Accu }\end{array}$ & $\begin{array}{c}4 \text { buah accu } \\
\text { terhubung seri }\end{array}$ \\
\hline Arus perjam (Ah) & $50 \mathrm{Ah}$ & $50 \mathrm{Ah}$ \\
\hline Tegangan Accu & $12 \mathrm{~V}$ & $48 \mathrm{~V}$ \\
\hline Daya dalam Wh & $600 \mathrm{wh}$ & $2400 \mathrm{wh}$ \\
\hline
\end{tabular}

Dalam kondisi terhubung seri didapatkan tegangan kerja baterai sebesar $48 \mathrm{~V}$ menyesuaikan tegangan kerja motor BLDC yang digunakan, dengan kapasitas $2400 \mathrm{Wh}$.

Waktu Pemakaian accu $=\frac{\text { Kapasitas accu }}{\text { Arus kerja motor }}=\frac{50 \mathrm{Ah}}{1,55}$

$=32,25 \sim 32 \mathrm{jam}$

Menggunakan accu otomotif (Diefisiensi accu 50\%) $=32 \mathrm{x}$ $50 \%=16 \mathrm{jam}$

Total pemakaian $=32-16=16$ jam .

3. Menghitung Kebutuhan Solar Cell

Dengan total daya motor yang digunakan sebesar $>350 \mathrm{Wh}$, maka panel surya yang digunakan berkapasitas $150 \mathrm{Wp}$ dan 260WP. 
Waktu yang diperlukan untuk pengisian accu selama :

Waktu Pengisian $=\frac{\text { Kapasitas Accu }}{\text { Besar Arus Charging }}+\left(20 \% \frac{\text { Kapasitas Accu }}{\text { Besar Arus Charging }}\right)$

$$
\begin{aligned}
& =\frac{50 A h}{7,07}+\left(20 \% \frac{50 A h}{7,07}\right) \\
& =8,48 \sim 8 \mathrm{jam}
\end{aligned}
$$

\section{F. Wirirng Diagram}

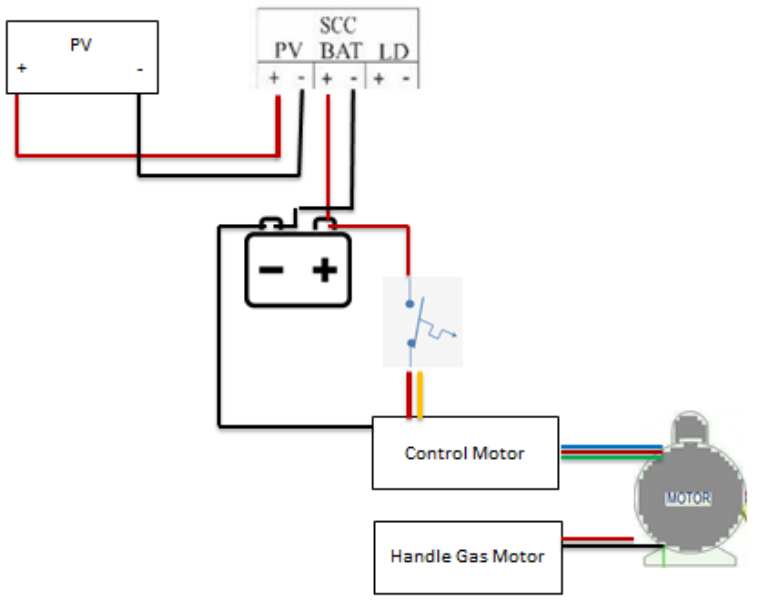

Gambar 3. Wiring Diagram

\section{Hasil dan Analisa}

\section{A. Rancangan Alat}

Tampilan fisik mesin pengayak pasir dapat dilihat pada gambar dibawah ini :

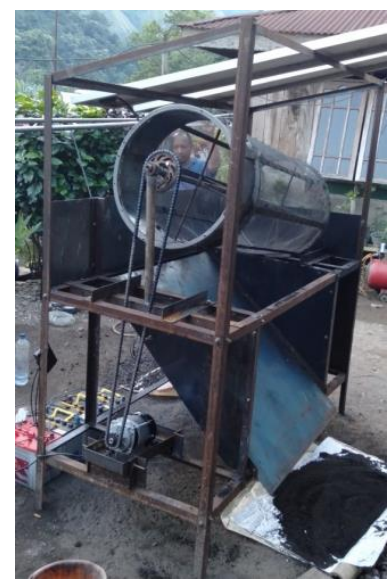

Gambar 4. Mesin Pengayak Pasir
Dapat dilihat bentuk fisik mesin pengayak pasir pada gambar diatas. Media pengayak berupa tabung ayakan yang diletakkan pada tengah mesin. Ketika proses pengayakan, pasir halus yang dihasilkan akan tersaring dan keluar melalui pembuangan bagian depan mesin sedangkan kerikil akan terbuang melalui pembuangan bagian belakang mesin. Mesin pengayak pasir ini dilengkapi dengan panel suya yang dipasang pada atap mesin sebagai supply listrik utama. Motor listrik, rantai dan gear, accumulator, solar charger controller dan control motor diletakkan pada samping kiri mesin dan bawah mesin.
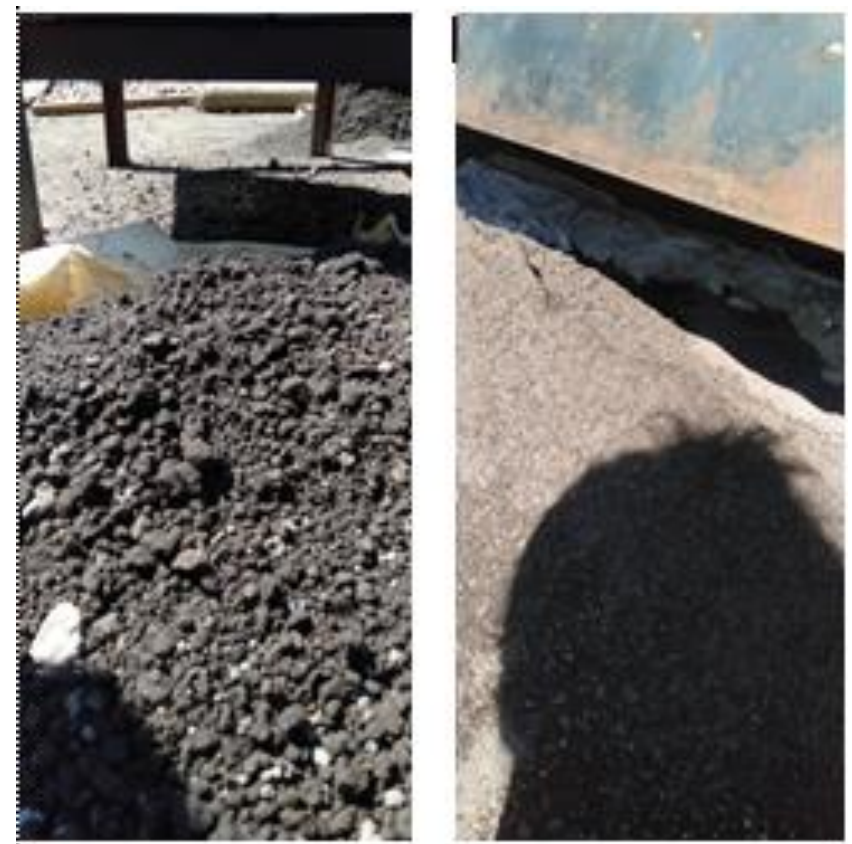

Gambar 5. Kerikil dan Pasir Halus Yang Dihasilkan

B. Pengukuran Kecepatan Motor Dengan Waktu Pengayakan Dari hasil pengukuran didapatkan data sebagai berikut : 
Tabel 2. Data Pengukuran Kecepatan dan Waktu

Pengayakan Terhadap Massa Pasir

\begin{tabular}{|c|c|c|c|}
\hline Parameter & $\begin{array}{c}\text { Kecepatan } \\
\text { motor } \\
\text { (rpm) }\end{array}$ & $\begin{array}{c}\text { Waktu } \\
\text { Pengayakan } \\
\text { (detik) }\end{array}$ & $\begin{array}{c}\text { Massa } \\
\text { Pasir } \\
(\mathrm{kg})\end{array}$ \\
\hline $\begin{array}{c}\text { Kecepatan } \\
1\end{array}$ & 147 & 18,77 & \\
\hline $\begin{array}{c}\text { Kecepatan } \\
2\end{array}$ & 386 & 15,28 & \multirow{2}{*}{$10 \mathrm{Kg}$} \\
\hline $\begin{array}{c}\text { Kecepatan } \\
3\end{array}$ & 425 & 12,03 & \\
\hline $\begin{array}{c}\text { Kecepatan } \\
4\end{array}$ & 547 & 07,84 & \\
\hline
\end{tabular}

Dari tabel 2 diatas, dibuat grafik hubungan antara kecepatan motor dengan waktu pengayakan terhadap massa pasir 10kg pada grafik 1 berikut:

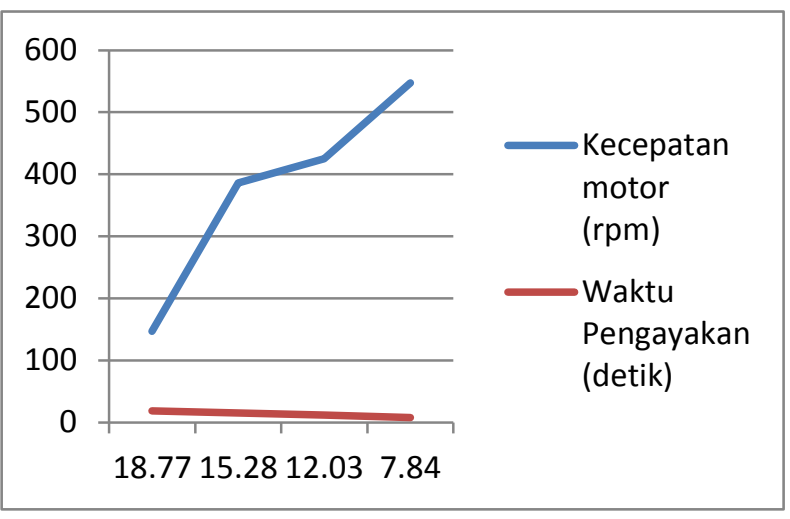

Grafik 1. Hubungan Antara Kecepatan Motor Dengan

Waktu Pengayakan

Dari tabel dan grafik diatas dapat dilihat bahwa ketika parameter kecepatan motor ditingkatkan, nilai kecepatan putaran motor (rpm) semakin besar. Nilai kecepatan putaran motor (rpm) berpengaruh pada waktu pengayakan pasir.
Semakin besar kecepeatan putaran motor maka waktu pengayakan semakin singkat.

C. Pengukuran Kecepatan Putar Tabung Tanpa Beban dan Berbeban

Tabel 3. Data Pengukuran Putaran Tabung Tanpa Beban dan Berbeban

\begin{tabular}{|c|c|c|}
\hline Parameter & $\begin{array}{c}\text { Kecepatan } \\
\text { tabung tanpa } \\
\text { beban (rpm) }\end{array}$ & $\begin{array}{c}\text { Kecep tabung } \\
\text { berbeban } \\
\text { (rpm) }\end{array}$ \\
\hline $\begin{array}{c}\text { Kecepatan } \\
1\end{array}$ & 118 & 101 \\
\hline $\begin{array}{c}\text { Kecepatan } \\
2\end{array}$ & 235 & 207 \\
\hline $\begin{array}{c}\text { Kecepatan } \\
3\end{array}$ & 241 & 212 \\
\hline $\begin{array}{c}\text { Kecepatan } \\
4\end{array}$ & 331 & 218 \\
\hline
\end{tabular}

Dari tabel 3 diatas, dibuat grafik perbandingan putaran tabung saat berbeban dan ketika tidak diberi beban pada grafik 2 berikut :

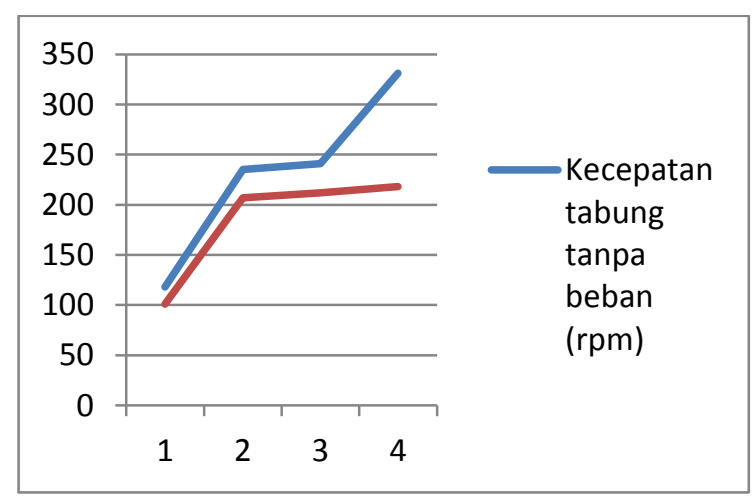

Grafik 2. Perbandingan Kecepatan Putaran Tabung 
Dari tabel diatas dapat dilihat bahwa ketika parameter kecepatan motor ditingkatkan, putaran tabung ketika di beri beban pasir dan tidak diberi beban pasir mengalami kenaikan. Namun ketika tabung diberi beban pasir kecepatan putarannya lebih kecil dibandingkan putaran tabung saat tidak dibebani. Hal ini dikarenakan pada tabung ayakan yang diberi beban terjadi hambatan yang disebabkan oleh tekanan dari berat pasir. Tekanan ini menyebabkan putaran berkurang.

\section{Pengukuran dan Perhitungan Tegangan dan Arus Motor}

\section{Terhadap Kecepatan Motor}

Tabel 4. Data Pengukuran dan Perhitungan Motor

\begin{tabular}{|c|c|c|c|c|c|c|}
\hline $\begin{array}{c}\text { Kecepata } \\
\text { n Motor } \\
(\mathrm{rpm})\end{array}$ & $\begin{array}{c}\text { Teganga } \\
\mathrm{n}(\mathrm{V})\end{array}$ & $\begin{array}{c}\text { Aru } \\
\mathrm{s} \\
(\mathrm{A})\end{array}$ & $\begin{array}{c}\text { Pinpu } \\
\mathrm{t} \\
\text { motor } \\
(\mathrm{W})\end{array}$ & $\begin{array}{c}\omega \\
(\mathrm{rad} / \mathrm{s} \\
)\end{array}$ & $\begin{array}{c}\text { Morsi } \\
\mathrm{r} \\
(\mathrm{Nm})\end{array}$ & $\begin{array}{c}\text { Poutp } \\
\mathrm{ut}(\mathrm{w})\end{array}$ \\
\hline 147 & 49,39 & 2,1 & $\begin{array}{c}103,1 \\
9\end{array}$ & 15,4 & 6,7 & 103,18 \\
\hline 386 & 48,99 & 1,6 & 78,38 & 40,4 & 1,9 & 76,76 \\
\hline 425 & 48,79 & 1,3 & 63,4 & 44,5 & 1,4 & 62,3 \\
\hline 547 & 47,55 & 1,2 & 57,1 & 57,2 & 0,9 & 57,2 \\
\hline Rata- & 48,68 & 1,5 & 75,5 & & & 74,7 \\
rata & & 5 & & & & \\
\hline
\end{tabular}

Perhitungan nilai Pinput motor (W) menggunakan persamaan :

$$
\mathrm{P}=\mathrm{V} \times \mathrm{I}
$$

Dengan $\mathrm{V}=$ nilai tegangan motor(volt), dan $\mathrm{I}=$ nilai arus motor (ampere)

Perhitungan kecepatan sudut $\omega(\mathrm{Rad} / \mathrm{s})$ menggunakan persamaan :

$$
\omega=\frac{2 \pi n}{60}
$$

Dengan $\pi=3,14$, dan $\mathrm{n}=$ kecepatan putar motor $(\mathrm{rpm})$
Perhitungan torsi motor $(\mathrm{Nm})$ menggunakan persamaan :

$\mathrm{T}=\frac{60 \mathrm{~W}}{2 \pi n}$

Dengan $\mathrm{W}=$ Pinput motor $(\mathrm{w}), \pi=3,14$, dan $\mathrm{n}=$ kecepatan putar motor (rpm)

Perhitungan Poutput motor (w) menggunakan persamaan :

Poutput $=$ Tx $\omega$

Dari table diatas diketahui bahwa semakin besar kecepatan putar motor (rpm), nilai tegangan motor dan arus motor yang dihasilkan mengalami penurunan. Berdasarkan hasil perhitungan pada table disimpulkan pula bahwa nilai daya masukan dan daya keluaran motor mengalami penurunan. Kecepatan putaran motor juga mempengaruhi torsi motor. Semakin besar kecepatan putaran motor maka semakin kecil nilai torsi motor.

Berdasarkan hasil perhitungan daya input motor dan output motor pada tabel diatas maka ditentukan nilai efisiensi yang dihasilkan oleh motor dengan persamaan berikut :

$$
\begin{gathered}
\eta=\frac{\text { Pout }}{\text { Pin }} \times 100 \% \\
\eta=\frac{74,7}{75,5} \times 100 \% \\
=99 \%
\end{gathered}
$$

\begin{tabular}{|c|c|c|c|}
\hline \multirow{2}{*}{$\begin{array}{c}\text { Waktu } \\
\text { Pengukura } \\
\text { n (Jam) }\end{array}$} & \multirow[b]{2}{*}{ Cuaca } & \multicolumn{2}{|c|}{ Panel Surya di Paralel } \\
\hline & & $\begin{array}{c}\text { Tegangan } \\
\text { (V) }\end{array}$ & Arus (A) \\
\hline 09.00 & Cerah & 43,3 & 6,2 \\
\hline 10.00 & Cerah & 46,0 & 8,3 \\
\hline 11.00 & Cerah & 45,36 & 6.8 \\
\hline 12.00 & Cerah Berawan & 44,33 & 7,1 \\
\hline 13.00 & Cerah Berawan & 45,0 & 7,8 \\
\hline 14.00 & Cerah Berawan & 45,25 & 7,8 \\
\hline
\end{tabular}

\section{E. Pengukuran dan Perhitungan Panel Surya}

Tabel 5. Data Pengukuran Panel Surya 


\begin{tabular}{|c|c|c|c|}
\hline 15.00 & Cerah Berawan & 44,7 & 7,3 \\
\hline 16.00 & Cerah Berawan & 43,13 & 6,1 \\
\hline 17.00 & Cerah & 43,65 & 6,3 \\
\hline \multicolumn{2}{|c|}{ Rata-rata } & 44,52 & 7,07 \\
\hline Poutput & \multicolumn{3}{|c|}{314,75} \\
\hline
\end{tabular}

Dari tabel 5 diatas, dibuat grafik hubungan antara intensitas cahaya matahari dengan nilai arus dan tegangan yang dihasilkan oleh pabel surya pada grafik 3 berikut :

Grafik 3. Hubungan Antara Intensitas Cahaya Matahari Dengan Tegangan dan Arus Yang Dihasilkan

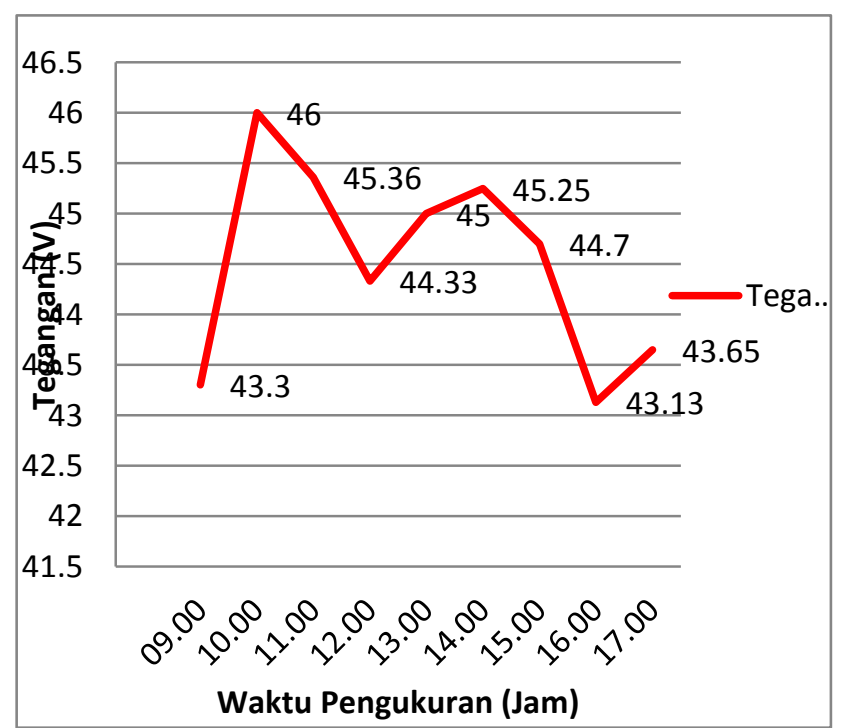

Berdasarkan tabel diatas diketahui bahwa waktu puncak penyinaran matahari terjadi pada pukul 10.00 dengan nilai tegangan dan arus yang dihasilkan sebesar 46,0volt dan 8,3 ampere. Terjadi fluktuasi penyinaran matahari menyebabkan nilai tegangan dan arus yang dihasilkan panel surya menjadi tidak stabil. Flukutasi intensitas cahaya matahair mempengaruhi nilai tegangan dan daya yang dihasilkan oleh panel surya.
Perhitungan nilai Poutput panel surya (W) menggunakan persamaan :

$\mathrm{P}=$ Vrata-rataxIrata-rata

\section{Kesimpulan}

Dari hasil pengujian dan analisa perhitungan yang dilakukan penulis, maka diperoleh kesimpulan sebagai berikut :

1. Rancang bangun mesin pengayak pasir yang memanfaatkan panel surya dan motor listrik ini memiliki keunggulan dapat mengayak pasir lebih cepat.

2. Waktu pengayakan bergantung pada kecepatan putaran motor. Semakin besar putaran motor maka waktu yang diperlukan untuk pengayakan semakin singkat.

3. Kecepatan putar motor berpengaruh pada tenaga putar motor (torsi). Semakin besar kecepatan motor maka torsi yang dihasilkan semakin kecil.

4. Intensitas cahaya matahari berpengaruh pada nilai tegangan dan arus yang dihasilkan oleh panel surya.

5. Motor BLDC yang dimanfaatkan sebagai penggerak mesin pengayak pasir semi otomatis ini diketahui sangat efisien dengan nilai efisiensi sebesar $99 \%$.

\section{Daftar Pustaka}

[1] B. H. Purwoto, I. F. Huda, F. Teknik, U. M. Surakarta, and P. Surya, "EFISIENSI PENGGUNAAN PANEL SURYA SEBAGAI SUMBER,”pp. 10-14, 2000.

[2] R. A. D. APRESCO, "Perbandingan Unjuk Kerja Notor Brushless Direct Current Dan Brushed Dc Pada Nogogeni Urban Konsep,” vol. 0, pp. 1-71, 2017.

[3] I. N. Sugiarta, Pengujian Open Circuit Voltage ( Voc ) Dan Short Circuit Current (Isc) Listrik Pada Rangkaian Seri Paralel Solar Cells Panel Di Politeknik 
Negeri Bali" vol. 14, no. 3, pp. 184-189, 2014.

[4] E. Roza and M. Mujirudin, "Perancangan Pembangkit Tenaga Surya Fakultas Teknik UHAMKA," Ejournal Kaji. Tek. Elektro, vol. 4, no. 1, pp. 16-30, 2019.

[5] R. J. Andika et al., "Pengendali Kecepatan Motor BLDC Berbasis PWM Pada Mobil” vol. 5, no. 1, pp. 48-54, 2018.

[6] M. Ma, D. Kurniawan, J. T. Mesin, F. Teknik, and U. N. Surabaya, "Analisa Kebutuhan Daya Motor Berdasarkan Kapasitas Mesin Peniris dan Pencampur Bumbu Makanan Ringan” pp. 17-25.

[7] A. Wolfgang, T. Senda, T. A. Riwu, and A. H. Andriawan, "Pengaturan Kecepatan Motor 3 Phase," no. 45, pp. 1-10, 1945.

[8] F. Fattah, "Rancang Bangun Alat Pengayak Pasir
Otomatis," vol. 01, no. 1, pp. 1-17, 2017.

[9] Y. M. Simanjuntak. (2017). "Studi Perencanaan Modul Praktikum PLTS".

[10] M. Syukri "Perencanaan Pembangkit Listrik Tenaga Surya ( PLTS ) Terpadu Menggunakan Software PVSYST Pada Komplek Perumahan di Banda Aceh" vol. 9, no. 2, 2010.

[11] R. A. D. Apresco. (2017). "Perbandingan Unjuk Kerja Notor Brushless Direct Current Dan Brushed DC Pada Nogogeni Urban Konsep”, vol. 0, pp. 1-71.

[12] Madichetty, Sreedhar., Pullaguram , Deepak . dan Mishra, Sukumar. (2019). "A Standalone BLDC Based Solar Air Cooler With MPP Tracking For Improved Efficiency", CSEE Journal of Power and Energy Systems, 5(1), pp. 111-119. 